\title{
BOEKRECENSIE
}

\section{Marie Elske Gispen, Human Rights and Drug Control ${ }^{*}$}

\author{
Prof. mr. J.C.J. Dute*
}

Op 20 januari 2017 promoveerde Marie Elske Gispen aan de Universiteit Utrecht op het proefschrift Human Rights and Drug Control. Promotores waren Jenny Goldschmidt en Marcus Düwell. Het proefschrift gaat over de toegankelijkheid van pijnmedicatie als morfine en codeine in onderontwikkelde landen. De toegang tot deze medicatie wordt bepaald door de internationale verdragen voor verdovende middelen, waarin regels zijn opgenomen voor medicinaal gebruik. De vraag is dan of en, zo ja, hoe het (internationale) drugsbeleid zou moeten worden aangepast als daarin de toegang tot pijnmedicatie centraal zou staan.

$\mathrm{Na}$ een tweetal inleidende hoofdstukken, waarin problematiek, vraagstelling, methode en achtergronden worden geschetst, volgen de centrale, theoretische hoofdstukken 3 en 4 . Hoofdstuk 3 analyseert het toepasselijke mensenrechtenkader en past dit toe op het zogenoemde 'evenwichtsprincipe' van de antidrugswetgeving. Dit principe verplicht overheden het gebruik van drugs voor medische (en wetenschappelijke) doeleinden te maximaliseren en de negatieve gevolgen van (recreatief) drugsgebruik te minimaliseren, een en ander binnen het stramien van een strikt verbod met specifieke uitzonderingen voor geneeskundig (en wetenschappelijk) gebruik. Op het eerste gezicht lijkt dit beginsel de toegang tot pijnmedicatie voldoende te borgen. Echter, het drugsbeleid ('the war on drugs') stelt bepaalde eisen die, zo niet de jure dan toch de facto, de toegang tot

* Marie Elske Gispen, Human Rights and Drug Control, Access to Controlled Essential Medicines in ResourceConstrained Countries, dissertatie, Cambridge: Intersentia 2017. ISBN 978-1-78068-454-3.

** Jos Dute is lid van het College voor de Rechten van de Mens, hoogleraar gezondheidsrecht te Nijmegen en redacteur van dit tijdschrift. pijnmedicatie belemmeren. Dan rijst de vraag welk belang (toegang tot basismedicatie of drugsbestrijding) voorgaat. Volgens Gispen kunnen binnen het mensenrechtenkader de relevante belangen beter tegen elkaar worden afgewogen. Zij komt uiteindelijk tot de conclusie dat het voorzien in de noodzakelijke pijnmedicatie meer gewicht in de schaal legt dan de bestrijding van de drugsproblematiek. Mensenrechtelijk gezien (meer in het bijzonder gelet op het recht op gezondheid en het verbod van onmenselijke behandeling) vraagt het eerste namelijk om onmiddellijke implementatie, het laatste slechts om geleidelijke implementatie. In hoofdstuk 4 wordt dit standpunt aan de hand van de ethische theorieën van Nussbaum en van Gewirth/Beyleveld verder onderbouwd.

In de hoofdstukken 5, 6 en 7 wordt verslag gedaan van een empirisch onderzoek naar de toegankelijkheid van pijnmedicatie in Oeganda en Letland. In de praktijk blijken op dit punt aanzienlijke belemmeringen te bestaan, die voortvloeien uit de administratieve, organisatorische, financiële, informationele en technische eisen die de antidrugswetgeving stelt. In slothoofdstuk 8 concludeert Gispen dat de toegang tot pijnmedicatie binnen het huidige drugsbeleid onvoldoende uit de verf komt. Zij bepleit een grondige, op mensenrechten gebaseerde aanpassing van het drugsbeleid, waarbij de toegang tot medicatie, en daarmee het belang van de patiënt, centraal komt te staan.

De beschikbaarheid van pijnmedicatie in onderontwikkelde landen is niet een probleem waarvan veel gezondheidsjuristen zich bewust zullen zijn. Gispen laat intussen zien dat het hier om een belangrijk volksgezondheidsvraagstuk gaat, dat met name kanker- en hiv-patiënten in onderontwikkelde landen treft. De waarde van het boek zit wat mij betreft 
echter vooral in het feit dat gedemonstreerd wordt dat het recht op gezondheid, en meer in het algemeen een mensenrechtelijke benadering, tot een radicaal andere aanpak van, in dit geval, het drugsbeleid noopt. Daarbij maakt Gispen ook inzichtelijk hoe desastreus een op papier evenwichtig uitziend beleid in de praktijk kan uitwerken. Of het ooit tot de door haar gewenste, op mensenrechten gebaseerde aanpak zal komen, blijft natuurlijk de vraag. Het drugsbeleid wordt immers in belangrijke mate bepaald door de mondiale politieke krachtsverhoudingen en die blijven in dit boek buiten beschouwing.

Gispen vergt wel het nodige van de lezer. Haar Engels is goed, maar het betoog verloopt traag en is nogal eens breed uitgesponnen, ook op punten waarover weinig discussie bestaat. Het ethische hoofdstuk staat of valt met de acceptatie van de opgevoerde theorieën en voegt wat mij betreft weinig toe. In plaats daarvan had ik liever een verbreding gezien naar eerdere juridische discussies over vergelijkbare probleemsituaties. Ook had ik graag wat nader uitgewerkt willen zien hoe een op mensenrechten gebaseerd drugsbeleid nu precies vorm dient te krijgen.

Niettemin, een proefschrift is eerst en vooral een proeve van wetenschappelijke bekwaamheid en die test heeft Gispen beslist goed doorstaan. Thans werkt zij in Groningen aan een project over kinderrechten en tabaksbeleid. Dat biedt haar de mogelijkheid om het mensenrechtelijke perspectief verder uit te bouwen, maar nu op een ander terrein, waar het recht op gezondheid evenzeer botst op andere belangen. Ik ben benieuwd. 